\title{
Problem-Based Learning in Static Fluid Topic of Physics Module
}

\author{
S.D. Aji, M.N. Hudha, C. Huda, Q. Aini \\ Universitas Kanjuruhan Malang \\ Malang, Indonesia \\ sudi@unikama.ac.id
}

\begin{abstract}
This research was intended to develop a physics module based on problem-based learning in static fluid topic to improve eleventh grade students' critical thinking skills. This study was Research and Development (R\&D) based on Brog and Gall. The instrument of this research is in the form of quality assessment sheet for physics module based on problem-based learning (PBL) distributed to a material expert, a media expert, teachers and students. The subjects of the research were one material expert, one media expert, two physics teachers and ten students as the research participants in the initial field test. The results of the study were: (1) a physics module based on problembased learning in static fluid topic to improve students' critical thinking skills, (2) the quality of PBL in static fluid subject of physics module from validator obtained a Very Good (VG) rating of the three aspects by 3.70 and (3) based on the students' response to the PBL in physics module, it was obtained "agree" (A) rating with an average rating 0.94 of the three aspects
\end{abstract}

Keywords-component; Learning physics, module, fluid topic.

\section{INTRODUCTION}

The ability to think critically in elementary school students is still considered necessary to be more developed. ${ }^{[10]}$ This is because teaching critical thinking is one of the important components in school's academic program (Carter \& Creedy, 2017). Critical thinking is needed to create a stronger interaction between students' 'soft skills' and 'hard skill' (Ku, Lee, \& Ellis, 2017).

Critical thinking is a fundamental skill that develops attractive learning activities and exercises as well as varied learning methods (Florea \& Hurjui, 2015). Critical thinking is a focal point (Thomas, Kevin, \& Aimee, 2016) in education and for students' academic achievement (Florea \& Hurjui, 2015). In addition, developing critical thinking skills can also improve the ability to draw conclusions and make informed decisions (Thomas et al., 2016).

Critical thinking can be improved through learning materials and media (Sirisopon \& Sopeerak, 2013). The teaching materials should be able to present problems that can stimulate students' thinking ability. PBL was considered able to improve students' critical thinking ability (Aji \& Hudha, 2016; Alrah-lah, 2016).

On the topic of fluid, students also experience difficulties because of some misconceptions such as objects drowned in the water because they are heavier than water, objects float on the water because they are lighter than water, the pressure and sforce are synonyms, and the pressure arises from the moving fluid (Suparno, 2005). Basically, the ability to think on the topic of fluid is a measurable ability to solve new problems, use logic in new situations, and identify them (Pagani, Brière, \& Janosz, 2017).

\section{METHOD}

This research used research and development model (R\&D). The purpose of this research and development model was to produce a physics module based on problem-based learning on the static fluid topic ${ }^{[11]}$. This module was expected to improve students' critical thinking skills, to be used as a learning resource independently by students, and to aid teachers in the learning process. This Research and development model adapted the research and development steps proposed by Borg \& Gall. The flowchart of the module development procedure can be seen in Figure 1.

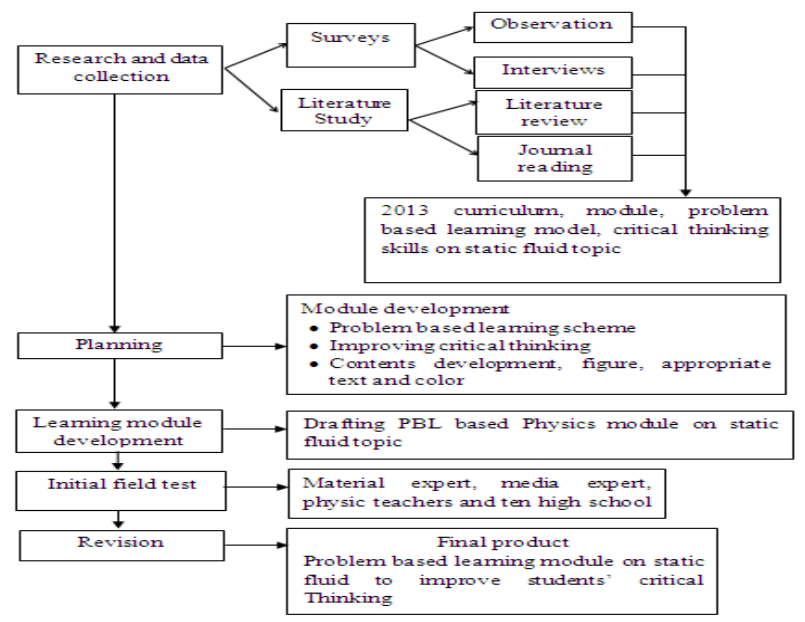

Fig. 1. Problem-based learning module development flowchart

The analysis technique used in this research and development was descriptive qualitative and quantitative analysis technique using percentage. The descriptive analysis was used to describe the results of development and 
quantitative analysis was used to analyze the results of validation and students' responses.

\section{RESULT AND DISCUSSION}

Module feasibility data was obtained from the material expert, media expert, and 2 high school physics teachers ${ }^{[12]}$. The data obtained consist of quantitative data and qualitative data. Quantitative data in the form of module assessment sheet was used to determine the feasibility of the module, while the qualitative data in the form of suggestions was used to improve the observer module. The Feasibility Test of Physics Module Based on Problem-based Learning from the material expert included the content feasibility aspects and the language feasibility aspects ${ }^{[14]}$. The feasibility of physics-based problembased learning module assessment from each aspect can be seen in Table 1 .

TABLE 1. MATERIAL EXPERT ASSESSMENT ON MODULE FEASIBILITY

\begin{tabular}{lll}
\hline \multicolumn{1}{c}{ Aspects } & \multicolumn{1}{c}{$\begin{array}{c}\text { Scores/ } \\
\text { Assessment }\end{array}$} & Category \\
\hline $\begin{array}{l}\text { Presentation } \\
\text { Feasibility }\end{array}$ & & \\
\hline $\begin{array}{l}\text { Module character } \\
\text { relevance }\end{array}$ & 3,80 & $\begin{array}{l}\text { Very Good } \\
\text { (VG) }\end{array}$ \\
\hline Enticement & 4,00 & $\begin{array}{l}\text { Very Good } \\
\text { (VG) }\end{array}$ \\
\hline Format & 3.50 & $\begin{array}{l}\text { Very Good } \\
\text { (VG) }\end{array}$ \\
\hline Organization & 3,67 & $\begin{array}{l}\text { Very Good } \\
\text { (VG) }\end{array}$ \\
\hline Size & 3,00 & Good (G) \\
\hline Space & 3,00 & Good (G) \\
\hline Average Score & 3,50 & $\begin{array}{l}\text { Very Good } \\
\text { (VG) }\end{array}$ \\
\hline $\begin{array}{l}\text { Language } \\
\text { Appropriateness }\end{array}$ & & \\
\hline $\begin{array}{l}\text { Language use } \\
\text { appropriateness }\end{array}$ & & \\
\hline Average Score & 3,75 & $\begin{array}{l}\text { Very Good } \\
\text { (VG) }\end{array}$ \\
\hline
\end{tabular}

After conducting the feasibility test of the module by the material expert and the media expert, the next step was the feasibility test of the physics module based on problem-based learning by the two high school physics teachers. The feasibility of physics-based problem-based learning module assessment from two high school physic teachers can be seen in Table 2.

TABLE 2. PHYSICS TEACHERS MODULE ASSESSMENT

\begin{tabular}{llll}
\hline No & \multicolumn{1}{c}{ Aspects } & $\begin{array}{c}\text { Scores/ } \\
\text { Assessment }\end{array}$ & \multicolumn{1}{c}{ Category } \\
\hline Content Appropriateness & & \\
\hline 1. & $\begin{array}{l}\text { Learning Objective } \\
\text { Relevance }\end{array}$ & 3,83 & $\begin{array}{l}\text { Very Good } \\
\text { (VG) }\end{array}$ \\
\hline 2. & Content Appropriateness & 4,00 & $\begin{array}{l}\text { Very Good } \\
\text { (VG) }\end{array}$ \\
\hline 3. & $\begin{array}{l}\text { Problem } \\
\text { Based Learning }\end{array}$ & 3,80 & $\begin{array}{l}\text { Very Good } \\
\text { (VG) }\end{array}$ \\
\hline
\end{tabular}

\begin{tabular}{llll}
\hline & Characteristics & & \\
\hline 4. & Critical Thinking & 3,70 & $\begin{array}{l}\text { Very Good } \\
\text { (VG) }\end{array}$ \\
\hline 5. & Content Systematics & 3,75 & $\begin{array}{l}\text { Very Good } \\
\text { (VG) }\end{array}$ \\
\hline 6. & $\begin{array}{l}\text { Practice and } \\
\text { experiment activities }\end{array}$ & 3,75 & $\begin{array}{l}\text { Very Good } \\
\text { (VG) }\end{array}$ \\
\hline & Average Score & 3,81 & $\begin{array}{l}\text { Very Good } \\
\text { (VG) }\end{array}$ \\
\hline
\end{tabular}

The material experts gave 3.73 (Very Good) for the content aspect, and high school physics teachers gave 3.81 (Very Good) (can be used without revision) for the quality of the of PB physics learning module on the static fluids topic. In terms of presentation aspect, the media expert gave 3.50 (Very Good) and the high school physics teachers gave 3.68 (Very Good). In addition, for the feasibility of the language aspect, material expert, media ex pert and the physics teacher gave 3.75 (Very Good) Finally, the students' responses toward the module are 0.94 (Agree) for the presentation aspect, 1.00 (Agree) for the language use aspect, and 0.87 (Agree) for the content appropriateness aspect.

The results of the analysis of the learning module by the students are presented in Table 3.

TABLE 3. THE RESULT OF STUDENT'S RESPONSES ON THE PHYSICS MODULE

\begin{tabular}{llll}
\hline No Aspects & $\begin{array}{l}\text { Scores/ } \\
\text { Assessment }\end{array}$ & Category \\
Presentation Aspect & 0,93 & Agree \\
\hline $1 . \quad$ Enticement & 0,95 & Agree \\
\hline $2 . \quad$ Fonts and font Size & 0,94 & Agree \\
\hline \multicolumn{3}{l}{ Average Score } & Agree \\
\hline Language Aspects & 1,00 & Agree \\
\hline $1 . \quad$ The Use of good and & Agree \\
\hline & acceptable sentences & Agree \\
\hline Content Aspects & 1,00 & \\
\hline $1 . \quad$ Content Relevance & 0,83 & Agree \\
\hline $2 . \quad$ Problem Based & 0,90 & Agree \\
\hline & Learning & & \\
\hline 3. & Characteristics & 0,88 & 0,87 \\
\hline
\end{tabular}

\section{CONCLUSION}

Number figures consecutively in the order in which reference is made to them in the text made no distinction between diagrams and photographs. Figures should fit within the column width of $90 \mathrm{~mm}$ (3.54") or within the type area width of $187 \mathrm{~mm}(7.36 ")$.

Figures, photographs, etc. can be in black/white or full color, but will be produced in the book in black/white only. Please insert the high-resolution figures (see artwork document) in the word file. Figures, etc. should not be centered but placed against the left margin. Leave about two lines of space between the actual text and figure (including caption).

Never place any text next to a figure. Leave this space blank. The most convenient place for placing figures is at the top or bottom of the page. Avoid placing text between figures as readers might not notice the text. Keep in mind that 
everything will be reduced to $75 \%$. Therefore, 9 points should be the minimum size of the lettering. Lines should preferably be $0.2 \mathrm{~mm}\left(0.1^{\prime \prime}\right)$ thick. Keep figures as simple as possible. Avoid excessive notes and designations.

\section{REFERENCES}

[1] Aji, S. D., \& Hudha, M. N. 2016. Kerja Ilmiah Siswa SMP dan SMA melalui authentic Problem Based Learning (aPBL). Jurnal Inspirasi Pendidikan, 6(1).

[2] Alrahlah, A. 2016. How effective the problem-based learning (PBL) in dental education. A critical review. The Saudi Dental Journal, (August). https://doi.org/10.1016/j.sdentj.2016.08.003

[3] Carter, A. G., \& Creedy, D. K. 2017. Author's Accepted Manuscript. Midwifery. https://doi.org/10.1016/j.midw.2017.08.003

[4] Florea, N. M., \& Hurjui, E. 2015. Critical thinking in elementary school children. Procedia - Social and Behavioral Sciences, 180(November 2014), 565-572. https://doi.org/10.1016/j.sbspro.2015.02.161

[5] Ku, K. Y. L., Lee, V. S. L., \& Ellis, J. 2017. Using Artwork as Problem Context in Generic Critical Thinking Instruction: A Strategy for Thoughts. Thinking Skills and Creativity. https://doi.org/10.1016/j.tsc.2017.07.001

[6] Pagani, L. S., Brière, F. N., \& Janosz, M. 2017. Intelligence Fluid reasoning skills at the high school transition predict subsequent dropout is. Intelligence. https://doi.org/10.1016/j.intell.2017.02.006

[7] Sirisopon, N., \& Sopeerak, S. 2013. Web-based Instruction Model under Constructionism for Critical Thinking Development. Procedia - Social and Behavioral Sciences, 103, 1309-1318 https://doi.org/10.1016/j.sbspro.2013.10.461
[8] Suparno, P. 2005. Miskonsepsi \& Perubahan Konsep Dalam Pendidikan Fisika. Jakarta: PT. Grasindo.

[9] Thomas, E., Kevin, E. H., \& Aimee, Y. F. C. 2016. Development of the Critical Thinking Toolkit (CriTT): A measure of student attitudes and beliefs about critical thinking. Thinking Skills and Creativity. https://doi.org/10.1016/j.tsc.2016.11.007

[10] Lai, Emily R. 2011. Critical Thinking: A Literature Review. Research Report.https://images.pearsonassessments.com/images/tmrs/CriticalThin kingReviewFINAL.pdf

[11] Fernandez, Flavian Brian. 2017. Action research in the physics classroom: the impact of authentic, inquiry-based learning or instruction on the learning of thermal physics. https://www.springeropen.com/track/pdf/10.1186/s41029-017-0014$\mathrm{z}$ ?site=apse-journal.springeropen.com

[12] Chotimah, Husnul dkk. 2017. Development of Biology Modules with Think Pair Share Strategy as an Effort to Improve Cognitive Learning Outcomes of Vocational Students. http://www.ijrrjournal.com/IJRR_Vol.4_Issue.6_June2017/IJRR002.pdf

[13] Kadarmanto, Agus. 2017. Validity Of Basic Physics Module Of Cac Model To Improve Higher Order Thinking Skills Of College Students. http://www.journalijar.com/uploads/149_IJAR-20138.pdf

[14] Fajarini, Anindya dkk. 2016. Developing A Social Studies Module by Using $\mathrm{P}$ roble $\mathrm{m}$ Based Learning (PBL) With Scaffolding for the Seventh Grade Students in A Junior High School in Malang, Indonesia. http://www.iosrjournals.org/

[15] Kampen, Paul Van. 2003. Teaching a single physics module through Problem Based Learning in a lecture-based curriculum. https://pdfs.semanticscholar.org/f244/bbbf989c344ecf6a3d11cf2d62122 $82 \mathrm{f} 245 \mathrm{e} \cdot \mathrm{pdf}$ 